\author{
여성복 패션컬렉션에 표현된 플리츠 디자인의 특성 \\ - 2009년 F/W부터 2012년 S/S 까지 \\ 밀라노, 파리, 뉴욕 컬렉션을 중심으로 - \\ 타오샤 $^{* *}$ 권혜숙* \\ 상명대학교 디자인대학원 석사 ** \\ 상명대학교 디자인대학 패션디자인 전공 교수*
}

\title{
The Characteristics of Pleats Design which appeared in the 'Collections' of Paris, Milan, New York from 2009 F/W to 2012 S/S
}

\author{
Tao Sha** Kwon Haesook \\ Sangmyung Graduate Schoo ${ }^{* *}$ \\ Professor, Dept. of Fashion Design, College of Design, Sangmyung University*
}

\begin{abstract}
The main objective of this research was to understand the characteristics of pleats design through the analysis of modern female fashion as they appear in the 'Collections' from '09 A/W to '12 S/S.

Data collection of 1027 was done through the review of 'prêt-à-porter Collections' of three cities; Milan, New York, Paris. Along with the qualitative interpretation of pleats design, statistical analysis of frequency and $x^{2}-$ test were completed for data analysis.

The main findings were as follows;

1. The five types of pleats design were founded in the order of accordion, knife, box, inverted, and sunburst pleats. The frequency and ratio of pleats design occurency showed significant difference between collections.

2. There were significant difference between the types of pleats and their line characteristics of thickness, continuity, length, direction.

$=$ Thin fabrics with delicate fine folds were mainly appeared in accordion and sunburst pleats. On the other hand, midium thickness fabrics were used for knife, box \& inverted pleats, however, the different images were projected according to the width and the number of folds, characteristics of fabrics and textures.
\end{abstract}

Corresponding author: Kwon Haesook, Tel. + 82415505201, Fax. +82415505206

E-mail: hskwon@smu.ac.kr 
$=$ In all the type of pleats but sunburst, continuity line was appeared the most. The discontinuous lines were appeared the most in the layered types and, sometimes, at some construction lines to add some decorative details or design variations.

$=$ The long line were the most frequently appeared in long one-pieces or long skirts of knife, accordion, sunburst pleats. While, the shorter lines showed the most frequently in box and inverted pleats, which mainly used for skirts or the lower part of one-piece.

$=$ For the line directions, the vertical lines were the most frequently appeared, and followed by mixed and diagonal line. In mixed or diagonal lines, same type of pleat was repeated in one design. For diagonal lines, one direction was mainly used, however, the symmetrical arrangements or repeated diagonal pleats in various directions also used. In mixed lines, the type of one or two diagonal and one vertical line was the most frequently appeared.

Key Words : Types of pleats(플리츠 유형), Thickness of line(선의 두께), Continuity of line (선의 연속성), Length of line(선의 길이), Direction of line(선의 방향).

\section{I. 서 론}

복식의 장식으로서의 잠재력은 커다란 감각적 만 족의 출처일 뿐 아니라 예술적 표현과 자기표현을 위한 중요한 출구이다. 복식의 장식성을 높이기 위 해 과거로부터 퀼팅(quilting), 패치워크(patchwork), 자수(embroiery), 펠팅(felting), 플리츠(pleats), 염색 (hand made dying) 등 여러 종류의 장식기법들이 발달되어 왔다. 이런 장식기법들은 조형예술로서 의 상의 감각적 표현에 일익을 담당하고 있으며 ${ }^{1)}$ 의상 의 부가가치성을 높여주는 하나의 방법이 될 수도 있다. 특히 다양한 장식기법 중 플리츠 기법은 특유 의 구조적인 조형감으로 인하여 고대로부터 현대까 지 폭넓게 사용되어 왔다.

최근에는 다양한 플리츠 디자인들이 해외 컬렉션 에서 주요한 비중을 차지하고 새로운 트랜드로 다시 주목 받고 있다.

“한 동안 옷장에서 잠자고 있던 플리츠 스커트 들 이 다시 한 번 빛을 보는 날이 왔다. 이번 시즌 레 이디 룩의 귀환과 함께 많은 디자이너들이 주름이 들어간 스커트들을 선보였기 때문. $\cdots$ 한 동안 찾아 보기 힘들었던 플리츠 스커트 들이 올 가을 다양한 모습으로 돌아왔기 때문이다.")

이처럼 플리츠는 장식적 기능뿐만 아니라 인체의 움직임을 원활하게 해주는 기능적인 측면도 지니고 있으며, 또한 선의 반복에 의한 독특한 조형적 특성
을 지니고 있어 패션디자인 뿐 아니라 의복구성, 소 재 관련 등 다양한 연구자들의 관심을 받아왔다.

플리츠의 가장 중요한 조형적 요소는 선으로, 패 션디자인에 있어 선이 차지하는 역할은 매우 중요하 고도 광범위하다. ${ }^{3)}$ 선은 길이와 넓이의 시각적 구분 을 가능하게 해주며, 사물의 형태를 형성하고, 동세 와 방향을 유도한다. 선은 의복 전체 속에서 시각적 인 방향과 흥미를 결정하는 요소로 어떠한 선을 사 용하는가에 따라 선이 모여서 만들어지는 2 차원과 3 차원적 형태에 대한 시각적 인식의 방법이 다를 뿐 만 아니라 패션 디자인의 이미지도 변화되어 다양하 게 표현된다. 즉, 선은 가고 있는 방향으로 시선을 유도하며, 통과하는 부분을 분할하여 공간에 분할점 을 제공하고, 연속적인 길을 따라 둘 이상의 점들을 연결시키거나 형이나 실루엣을 한정할 수 있으며, 또한 성격이나 분위기를 전달한다. 이러한 의복에서 의 선은 실루엣선, 디테일, 트리밍, 구성선, 문양 등 으로 나타나고 이로 인한 시각적인 착시효과를 유도 하는 등 다양한 미적 표현이 가능하다. ${ }^{45)}$

플리츠에 관한 선행 연구들은 주로 플리츠의 미적 효과나 플리츠 기법을 응용한 제작법 등을 중심으로

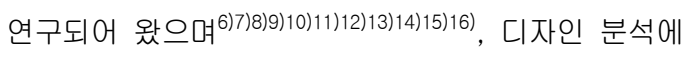
서는 형태의 미적 특성 분석 위주의 질적연구들 17)18191920)로 진행되어 실제 컬렉션에서는 어떠한 유 형의 플리츠가 비중 있게 소개 되었는지에 대한 양 
적 분석을 병행한 연구는 미흡한 편이다. 김지영 $(2005)^{21)}$ 의 경우 해외 컬렉션에 나타난 주름 디자인 의 빈도 분석을 진행하였으나 그 분석대상이 2000 년 S/S 시즌부터 2005년 S/S 시즌까지로, 현대 패 션의 유행 주기가 3 5년 정도인 점을 감안할 때 해 당연구의 분석결과를 현재에 적용하기에는 무리가 있다.

본 연구의 주된 목적은 2009년 $\mathrm{F} / \mathrm{W}$ 2012년 $\mathrm{S} / \mathrm{S}$ 까지 주요한 해외 컬렉션에 소개된 플리츠를 활 용한 최신의 디자인들을 중심으로 패션에 나타난 플 리츠의 유형 및 그 유형별 디자인 특성을 살펴보는 것이다. 이를 위하여 플리츠의 가장 중요한 조형적 요소인 선과 선의 반복에 의한 리듬으로 인하여 야 기되는 시각적 효과에 중점을 두고 연구를 진행하고 자 한다. 또한 양적-질적인 분석을 병행함으로서 보 다 과학적이면서도 체계적인 디자인 분석을 진행하 고자 한다. 이를 통해 플리츠와 관련된 디자인의 최 신 트랜드 경향을 파악하고 아울러 실제 디자인 아 이디어에도 유용하게 사용될 수 있는 실용적 자료를 제공하고자 한다.

\section{II. 이론적 배경}

\section{1. 플리츠의 용어정의}

플리츠의 사전적 용어정의를 김창준(1991)과 박기 원(1978)은 접은 주름으로 그 기능은 장식효과와 입 체감을 겸한다. 중세에 영국에서는 이것을 플래트 (Plait)라고 했다",22)23)고 언급하였다. 또한 Wikipedia 에는 '직물을 안쪽으로 두 배로 접어 넣어 고정시킨 주름의 한 유형으로, 의복이나 실내장식 직물에 주 로 사용된다. 열처리에 의한 프레스 형태와 프레스 를 가하지 않은 형태로 분류된다. ${ }^{24)}$ 고 언급되어 있 다.

이러한 용어정의를 중심으로 정리해 보면, 플리츠 는 '주름의 한 유형으로 인위적으로 접혀진 형태의 주름'으로 볼 수 있을 것이다.

\section{2. 플리츠의 유형}

플리츠 유형을 파악하기 위하여 3 개의 복식사전(解 服饰用语事典，1978; 服饰辞典， 1991; Fairchild's Dictionary of Fashion, 2002) ${ }^{25}$ 과 6 개의 선행연구 들(손영미 외, 2004; 김경희, 2006; 이유경,1993; 이은경,1991; 신윤미, 1997; 김지영, 2004)에 나타 난 플리츠의 유형과 그 유형별 빈도를 살펴본 결과, 플리츠의 유형은 총 26 개로 매우 다양하게 나타나고 있었다.<표 1>

\section{3. 플리츠의 시각적 효과}

1) 선의 종류와 특성에 따른 조형적 특성

선의 특성을 분석하는 경우 그 분석 대상이 되는 측면, 즉 분류 항목, 내용 등은 연구자에 따라 다소 다르다. 그러나 일반적으로 선의 특성은 선의 모양 과 관련된 경로, 두께, 선의 매끄러운 정도, 연속성, 가장자리의 윤곽의 모양과 날카로움 정도, 일관성, 길이, 그리고 방향 등의 아홉 가지 측면과 관련이 깊은 것으로 나타나 있다. 기존의 관련 문헌들에는 각 변인별 하위변인의 유형과 하위변인별 형태, 외 관 및 신체적·심리적 효과와 사용방법 등을 제시하 고 있다. 그러나 선의 특성을 분석하는 특성 요인의 수와 내용과는 무관하게 선의 다양한 측면들은 각각 의 많은 변이를 가지고 있다. 예를 들어, 두께는 매 우 얇고 섬세한 것에서 매우 두꺼운 것까지의 범주 가 가능하고, 연속성은 여러 가지 방법으로 연속되 거나 단절될 수 있다. ${ }^{26)}$ 따라서 연구하고자 하는 목 적에 적절하도록 선의 특성을 분류하는 요인들을 선 정하는 과정이 요구된다고 볼 수 있다.

본 연구에서의 플리츠는 직선으로 이루어진 경우 를 의미하는 것이므로 직선의 특성을 중심으로, 그 리고 그 외에는 플리츠 디자인의 시각적 평가에 가 장 많은 영향을 미칠 수 있는 선의 두께와 연속성, 그리고 길이와 방향의 네 가지 속성과 관련된 부분 들을 중심으로 관련 문헌들 27/288229)에 나타난 선의 특 성을 살펴본 결과, <표 2>와 같았다. 
<표 1> 선행연구와 관련 문헌들에 나타난 플리츠의 유형 및 유형별 사용 빈도

\begin{tabular}{|c|c|c|c|c|c|c|c|c|c|c|}
\hline 플리츠유형 & $\begin{array}{l}\text { 圖解服饰 } \\
\text { 用语事典 }\end{array}$ & $\begin{array}{l}\text { 服饰 } \\
\text { 辞典 }\end{array}$ & $\begin{array}{l}\text { Fairchild's } \\
\text { Dictionary } \\
\text { of Fashion }\end{array}$ & $\begin{array}{l}\text { 손영미 } \\
\text { (외) } \\
\text { (2004) }\end{array}$ & $\begin{array}{l}\text { 김경희 } \\
\text { (2006) }\end{array}$ & $\begin{array}{l}\text { 이유경 } \\
\text { (1993) }\end{array}$ & $\begin{array}{l}\text { 이은경 } \\
\text { (1991) }\end{array}$ & \begin{tabular}{|l|} 
신윤미 \\
(1997)
\end{tabular} & \begin{tabular}{|l|} 
김지영 \\
$(2004)$
\end{tabular} & 빈도 \\
\hline 나이프 플리츠 & 0 & 0 & 0 & 0 & 0 & 0 & 0 & 0 & 0 & 9 \\
\hline 박스 플리츠 & 0 & 0 & 0 & 0 & 0 & 0 & 0 & 0 & 0 & 9 \\
\hline 인버티드 플리츠 & 0 & & 0 & 0 & 0 & 0 & & 0 & 0 & 7 \\
\hline 아코디언 플리츠 & 0 & & 0 & 0 & 0 & 0 & 0 & & 0 & 7 \\
\hline 엄브렐러 플리츠 & 0 & 0 & 0 & & & & & 0 & & 4 \\
\hline 카트리지 플리츠 & 0 & & 0 & & & & & 0 & 0 & 4 \\
\hline 선버스트 플리츠 & 0 & 0 & 0 & & & & & 0 & & 4 \\
\hline 킥 플리츠 & 0 & & 0 & & & & & 0 & & 3 \\
\hline 엔지니어드 플리츠 & & & & 0 & & & 0 & & & 2 \\
\hline 선레이 플리츠 & & 0 & & & & & & 0 & & 2 \\
\hline 언프렌스트 플리츠 & 0 & & & & & & & 0 & & 2 \\
\hline 세로 플리츠 & & & & 0 & & & & & & 1 \\
\hline 가로선 플리츠 & & & & 0 & & & & & & 1 \\
\hline 아가일버들 플리츠 & & & & 0 & & & & & & 1 \\
\hline 트라이앵글 플리츠 & & & & 0 & & & & & & 1 \\
\hline 렌덤 플리츠 & & & & 0 & & & & & & 1 \\
\hline 웬웨이 플리츠 & 0 & & & & & & & & & 1 \\
\hline 퍼머넨트 플리츠 & 0 & & & & & & & & & 1 \\
\hline 팬 플리츠 & & & & & & & & 0 & & 1 \\
\hline 킬트 플리츠 & 0 & & & & & & & & & 1 \\
\hline 스티레이프 플리츠 & & & & & & & 0 & & & 1 \\
\hline 컨투어드 플리츠 & & & & & & & 0 & & & 1 \\
\hline 테이퍼드 플리츠 & & & & & & & 0 & & & 1 \\
\hline 턱 플리츠 & & & & & & & & 0 & & 1 \\
\hline 이레귤러 플리츠 & & & & & & & & & 0 & 1 \\
\hline 버블 플리츠 & & & & 0 & & & & & & 1 \\
\hline
\end{tabular}

위와 같은 플리츠의 선의 속성에 따른 효과에 더 불어, 플리츠의 선은 그 넓이나 수, 길이, 모양에 따 라 느낌이 다르다. 플리츠는 안정적이며 힘이 있는 느낌이나 모던한 느낌을 준다. 특히 단면이 지그재 그 형태로 나타나는 아코디언 플리츠는 뚜렷하고 날 카로운 느낌, 현대적인 느낌을 준다. 또한 넓은 간 격의 플리츠는 확실하고 단호한 느낌, 힘 있고 남성 스러운 느낌을 주는데 비해 좁은 간격의 플리츠는 섬세하고 여성스러운 느낌, 온화하고 미묘한 느낌을
준다. ${ }^{30)}$

2) 선의 반복에 의한 리듬

플리츠의 선은 반복의 형태가 보편적이다. 디자인 의 원리들 중 반복은 강조나 통일감을 얻게 하는 중 요한 원리이며 반복자체가 선의 구조적, 장식적 표 현에 이용된다. 플리츠의 반복에 의한 방향효과는 신체 위에서 방향성을 가지는 시각적 동세를 강조하 는 효과를 지닌다. 즉, 시선이 한 요소의 사용에서 
<표 2> 선의 속성과 효과

\begin{tabular}{|c|c|c|c|}
\hline 속성 & 변이 & 물리적 효과 & 심리적 효과 \\
\hline \multirow{2}{*}{ 두)ᄁㅔ } & 두꺼운 & 무게를 더한다. & $\begin{array}{l}\text { 힘이 있다. 공격적이다. 확실하고 } \\
\text { 남성다운. }\end{array}$ \\
\hline & 얇은 & 무게를 최소화 한다. & $\begin{array}{l}\text { 섬세한, 우미한, 여성다운, 수동적이다, } \\
\text { 고요하고 미묘한 느낌을 춘다. }\end{array}$ \\
\hline \multirow{2}{*}{ 연속성 } & 연속적인 & $\begin{array}{l}\text { 매끄러운 선들은 강화한다. } \\
\text { 부푼 것을 강조한다. }\end{array}$ & $\begin{array}{l}\text { 일관되다. 확실하다. 뚜렷하다. 우아한 } \\
\text { 끔을 춘다. }\end{array}$ \\
\hline & 절단된 & 불규칙성을 강조할 수 있다. & $\begin{array}{l}\text { 덜 확실하다. 스타카토, 중단된다. } \\
\text { 캐주얼한, 경쾌한 느낌을 준다. }\end{array}$ \\
\hline \multirow[t]{2}{*}{ 길이 } & 긴 & $\begin{array}{l}\text { 방향을 강조하고, 길어 보이게 하고 } \\
\text { 매끄넙게 한다. }\end{array}$ & 연속성, 부드럽고 우아한 흐름을 암시한다. \\
\hline & 짧은 & 공간을 쪼개고, 분주함을 증가시킨다. & 스타카토, 돌발적인 효과를 준다. \\
\hline \multirow{3}{*}{ 방향 } & 수직 & 길어 보이게 하고, 좁아 보이게 한다. & $\begin{array}{l}\text { 고상하고 장중한 느낌을 준다. 딱딱하고 } \\
\text { 위엄 있는 느낌을 준다. 신뢰감을 준다. }\end{array}$ \\
\hline & 수평 & 짧아 보이게 하고, 넓어 보이게 한다. & 안정감을 준다. 스포티한 느낌을 준다. \\
\hline & 사선 & $\begin{array}{l}\text { 주의 선들의 영향에 보다 많이 } \\
\text { 의존하게 한다. }\end{array}$ & $\begin{array}{l}\text { 가볍고 움직임이 있는 느낌을 준다. } \\
\text { 불안정한 운당을 준다. }\end{array}$ \\
\hline
\end{tabular}

그 요소의 반복사용으로부터 나오는 특정방향으로 움직이며, 인체 위에서 그 방향을 강조하는 방향의 원리로 작용한다. 그러므로 강조하고자 하는 방향으 로의 반복이 중요하다. ${ }^{31)}$

반복은 또한 디자인의 요소를 같은 양, 같은 간격 으로 되풀이하여 움직임을 느끼게 하는 것을 의미한 다. 그러므로 동질의 무게, 같은 크기의 강도, 밀도 를 가진 요소들이 되풀이 되어 움직임과 율동감을 주게 되므로 단순하지만 차분하고 안정감을 줄 수 있다. 그러나 일정하고 정확한 반복은 대조나 대립 이 없기 때문에 진정시키는 함이 있지만 지나치면 단조로움 야기 시킬 수도 있다. ${ }^{32)}$

한편 섬세하고 부드러운 시각적 감각은 곧 율동을 의미하는데, 율동은 근본적으로 동세와 관련된 것으 로, 흐르는 듯 혹은 분절적으로 표현되며, 명확하게 혹은 미묘하게 제시되기도 한다. 율동에 의한 리듬 의 효과는 그 단위가 생동적일수록 더욱 많은 관심 을 끌며 더 확대되어 보이게 된다. ${ }^{33)}$

이러한 리듬은 디자인에 변화와 흥미를 더해주는 원리이다. 반복은 가장 단순하고 기본적인 리듬의 유형으로 조직화된 운동에 대한 느낌으로 어떤 한 방향을 제시해야만 하는 움직임을 지니고 있음으로 방향의 원리라고도 할 수 있다. 리듬감은 매끄럽게
또는 강렬하게도 형성될 수 있는데, 심리적으로는 명확하게 혹은 미묘하게 등의 다양한 분위기를 표출 해 내고, 물리적으로는 신체 위의 움직임에 있는 방 향을 강조한다. 선의 경로, 두께, 연속성 등과 같은 선의 다양한 측면을 이용하면, 광범위하고 다양한 한 리듬감의 효과를 얻을 수 있다. 예를 들어 규칙 적인 절단선들은 분절의 효과를 나타내고, 두꺼운 선들은 단호하고 힘찬 리듬감을, 얇은 선들은 다소 경쾌하고 섬세한 리듬감을 나타낸다. 리듬감은 솔직 하게 나타난 경우보다는 거의 암시적으로 나타날 때 가 더욱 미묘하고 세련된 느낌을 주게 된다. 일반적 으로 리듬의 단위가 짧을수록 또는 매끄러울수록 효 과가 절묘하고 절정에 이르는 발전의 정도가 길수록 더욱 흥미로워지기는 하나, 절제된 표현이 더욱 강 한 힘을 지니게 한다는 점에 유의하여야한다. ${ }^{34)}$

위와 같이 다양한 플리츠의 시각적 효과와 그에 따른 감성적 표현 경향은 현대 패션에 나타난 플리 츠 디자인의 경향 분석에 적용되어 분석 결과의 해 석에 활용될 수 있을 것이다. 


\section{III. 연구방법 및 절차}

\section{1. 연구문제}

(1) 2009년 $\mathrm{F} / \mathrm{W}^{\sim 2012}$ 2년 $\mathrm{S} / \mathrm{S}$ 시즌 동안 파리, 밀라노, 뉴욕 3대 컬렉션에 나타난 플리츠 디자인의 유형 및 유형별 빈도는 어떠한가?

(2) 2009년 $\mathrm{F} / \mathrm{W}^{\sim}$ 2012년 $\mathrm{S} / \mathrm{S}$ 시즌 동안 파리, 밀라노, 뉴욕 3대 컬렉션에 나타난 플리츠 유형별 디자인의 조형적 특성을 선의 네가지 속성을 중심으 로 살펴본 결과는 어떠한가?

\section{2. 분석 자료의 선정 및 연구범위}

본 연구의 분석 자료는 해외 컬렉션을 가장 많이 보여주고 있는 ${ }^{\circledR G a p ~ C o l l e c t i o n s 』 ㅈ ㅣ ㄹ ㅗ, ~ 2009 ㄴ ㅕ ㄴ ~}$ F/W 2012년 S/S 까지의 6개 시즌 동안 출간된 총 18 권의 내용들 중 파리, 밀라노, 뉴욕 컬렉션만 을 선정하였다.

\section{3. 분석유목의 선정 기준 및 방법}

본 연구에 사용된 분석유목의 선정기준과 방법은 다음과 같다.

첫째, <표 1>에 나타난 결과를 중심으로 유형별 빈도를 살펴본 결과, 나이프 플리츠와 박스 플리츠 는 모든 문헌과 선행연구에서, 그리고 인버티드 플 리츠와 아코디언 플리츠은 7번, 엄브렐러 플리츠와 카트리지 플리츠, 선버스트 플리츠, 킥 플리츠는 각 4번씩 언급되거나 사용되고 있었다. 그러므로 이러 한 7 개의 플리츠 유형들을 우선적으로 연구대상으로 선정하여 예비실험을 실시한 결과, 세로 봉재기법을 응용하여 주름을 잡는 방식의 카트리지 플리츠는 컬 렉션지에 나타난 사진만으로는 개더를 사용하여 구 성된 형태와 그 시각적 차이를 구분하기 어려웠음으 로 연구대상에서 제외하였다. 그러므로 나이프 플리 츠, 박스 플리츠, 아코디언 플리츠, 인버티드 플리 츠, 선버스트 플리츠, 엄브렐러 플리츠의 총 여섯 유형이 본 연구의 분석유목으로 최종 선정되었다.

둘째, 본 연구에서의 플리츠의 조형적 특성을 파 악하기 위한 선의 속성과 관련된 분석유목 및 각 유
목별 하위요인은 관련 문헌들과 연구대상에 대한 예 비 조사를 거쳐 연구의 목적에 적절하도록 선정하였 다. 그 결과 두께의 경우는 '두꺼운', '중간', '얇은' 으로, 선의 연속성은 '연속’과 '불연속’으로, 길이는 '길다'와 ‘짧다'로, 그리고 방향은 '수직선', ‘수평선', '사선' 과 '혼합형'으로 분류하여 분석을 실시하였다.

\section{4. 연구 대상의 선정과 분석 방법}

연구대상은 우선 컬렉션에 나타난 디자인들 중 플 리츠를 사용한 디자인만을 선정하여 각 디자인에 사 용된 플리츠 디자인의 유형을 파악하였고 아울러 선 의 속성과 관련된 분석유목에 따라 어떠한 범주에 속하는가를 분류하였다.

이 후 파악된 양적 자료를 중심으로 플리츠 유형 별로 어떠한 조형적 특성을 지니고 있는가를 질적으 로 분석한 후 두가지 결과를 중심으로 결과를 분석 하였다.

이 과정에는 연구자와 더불어 의상 전공자 2 인이 참여하였으며, 분석자들 간에 이견이 발생한 경우에 는 제 3 자의 의견을 문의한 후 최종 판단하였다.

\section{5. 용어정의}

1) 플리츠 유형별 용어정의

본 연구에서 사용할 6개 플리츠의 유형별 용어정 의는 선행연구들을 중심으로 다음과 같이 선정되었 다.

-나이프 플리츠 : 동일 방향으로 주름을 잡은 형 태로 사용된 아이템이나 디테일 등에 전체적으로 사 용되거나 일부에 두 개 이상 반복하여 나타난 경우 를 포함.

-박스 플리츠 : 양단에 접은 선이 있는, 즉 맞주 름 형태가 두 개 이상 연속적으로 반복되는 경우로 박스형태가 외곽으로 나타나는 형태로, 마주하는 선 이 맞물린 경우와 약간 벌어진 형태를 포함한다.

-인버티드 플리츠 : 박스 플리츠가 하나만 나타난 경우로 박스 형태는 안쪽으로 들어가 밖으로는 슬리 트 형태의 선만 보이는 경우이다. 플리츠의 상단선 이 막힌 경우와 오픈된 형태 모두 포함한다. 
-아코디언 플리츠 : 아코디언의 주름상자와 같은 형태로 되어 있는 형태를 의미.

-선버스트 플리츠 : 아코디언 플리츠의 형태와 비 슷하나 밑단 부분에서 넓어지는 형태를 의미.

-엄브렐러 플리츠 : 우산처럼 양쪽 방향으로 주름 을 잡음

2) 선의 속성 관련 용어정의

-두)께: 플리츠를 이용한 디자인에 사용된 소재의 두께를 의미. '두꺼운', '중간', '얇은'으로 분류.

-연속성: 사용된 선이 시작부터 끝까지 끊이지 않

고 연속되었는지 혹은 어떤 지점이던 일시적으로나

마 연결이 중단되었는가를 의미. '연속'과 '불연속' 으로 분류.

-길이: 착용자의 신체길이와 사용된 플리츠 선의 길이와의 비율을 의미. '길다'와 '짧다'로 분류.

-방향: 플리츠의 선이 시선을 이그는 주된 방향을 의미하는 것으로 수직선, 수평선, 사선, 혼합형으로 분류. '혼합형'은 하나의 디자인에서 동일한 아이템 에 방향이 서로 다른 플리츠가 사용되거나 하나 이 상의 아이템에 서로 다른 방향의 플리츠가 사용되었 을 경우를 의미.

\section{6. 자료 분석 방법}

분석 유목별 플리츠의 유형 분류는 본 연구자 외 의상 전공자 2 명과 함께 실시하였다. 플리츠 유형별 분석자간의 일치도는 90 97\% 사이로 나타났다.

자료의 처리는 컬렉션별 플리츠 유형별 발생빈도 와 빈도율의 양적 차이를 알아보기 위하여 빈도 분 석을 사용하였고 이와 더불어 플리츠의 디자인의 특 성 파악을 위하여 질적 분석을 병행하였다. 플리츠 유형과 플리츠 디자인 선과 관련된 조형적 특성 선의 두께, 연속성, 길이, 방향 - 과의 유의한 차이 를 알아보기 위하여 $\chi^{2}-$ test를 실시하였다.

\section{IV. 연구 결과 및 분석}

2009년 $F / W^{\sim}$ 2012년 $S / S$ 까지의 기간동안
『Collections』지에 나타난 파리, 밀라노, 뉴욕 컬 렉션에는 나타난 총 디자인 발생빈도와 컬렉션별 발 생비율, 컬렉션별 플리츠 디자인 발생빈도와 빈도율 그리고 총 디자인수를 중심으로 본 컬렉션별 플리츠 디자인 발생빈도와 빈도율은 <표 3>과 같다.

연구대상에 포함된 총 16권의 3대 컬렉션에 나타 난 총 디자인은 23,865 개로, 파리컬렉션에서 9,603 개(40.2\%)로 가장 많은 디자인이 나타났으며, 그 다 음은 밀라노 컬렉션 9,471개(39.7\%), 그리고 뉴욕 컬렉션 4,791개(20.1\%)순이었다. 23,865개 중 플리 츠를 활용한 디자인은 1,207개(5.05\%)로 비교적 높 은 비율로 나타나 플리츠가 새로운 트랜드의 한 부 분을 차지하고 있음을 시사하고 있다.

플리츠 디자인의 발생빈도와 빈도율을 컬렉션별로 살펴보면, 밀라노 컬렉션이 552개(5.8\%)로 가장 높 게 나타났고, 파리는 438개(4.6\%) 그리고 뉴욕은 218 개(4.6\%)로 나타나, 두 도시 간의 발생 빈도율 (플리츠 디자인/총 디자인)에는 차이가 없는 것으로 나타났다.

이처럼 ${ }^{\circledR}$ Collections』지에 제시된 총 디자인의 수는 컬렉션 도시별로 다르게 나타났음으로 발생빈 도보다는 발생 빈도율을 중심으로 연구를 진행하였 고 연구결과는 다음과 같다.

\section{3대 컬렉션에 나타난 플리츠 디자인의 유형 및 유형별 빈도}

2009년 F/W 2010년 S/S시즌 동안 3대 컬렉션 에 나타난 플리츠의 유형은 총 6 개로, 나이프 플리 츠 344 개(28.6\%), 박스 플리츠 154개(12.3\%), 아코 디언 플리츠 583 개(48.4\%), 인버티드 플리츠 89 개 (7.4\%), 선버스트 플리츠 34 개(2.8\%), 그리고 엄브 렐러 플리츠 3 개 $(0.2 \%)$ 이었다. 6 개의 플리츠 유형들 중, 엄브렐러 플리츠는 총 3 개로 나타나 표본의 대 표성을 가질 수 없음으로 이를 제외시키고 나머지 5 개 유형을 중심으로 연구를 진행하였다.

5 개 플리츠 유형별 발생빈도와 빈도율이 컬렉션별 로 유의미한 차이가 있는가를 알아보기 위하여 $\chi$ 검 증을 실시한 결과, 유의한 차이가 있는 것으로 나타 났다. $\left(\chi^{2}=73.228 \mathrm{df}=8 \mathrm{p}<0.01\right)$ 
<표 4> 파리, 일라노, 뉴욕 컬렉션에 나타난 플리츠 유형별 발생 빈도와 빈도율

\begin{tabular}{|c|c|c|c|c|c|}
\hline 플리츠유홍시 명 & 파리 & 밀라노 & 뉴욕 & 전체 & $\chi^{2}$ 검증 \\
\hline 나이프 & $170(39.0 \%)$ & $134(24.4 \%)$ & $40(18.3 \% \%)$ & $344(28.6 \%)$ & \multirow{6}{*}{$\begin{array}{c}x^{2}= \\
73.228 \\
d f=8 \\
p<0.01\end{array}$} \\
\hline 박스 & $50(11.5 \%)$ & $73(13.3 \%)$ & $31(14.2 \%)$ & $154(12.8 \%)$ & \\
\hline 아코디언 & 158(36.2\%) & $303(55.1 \%)$ & $122(56.0 \%)$ & $583(48.4 \%)$ & \\
\hline 인버티드 & $33(7.6 \%)$ & $35(6.4 \%)$ & $21(9.6 \%)$ & $89(7.4 \%)$ & \\
\hline 선버스트 & $25(5.7 \%)$ & $5(0.9 \%)$ & $4(1.8 \%)$ & $34(2.8 \%)$ & \\
\hline 전체 & $436(36.2 \%)$ & $550(45.7 \%)$ & $218(18.1 \%)$ & $1204(100.0 \%)$ & \\
\hline
\end{tabular}

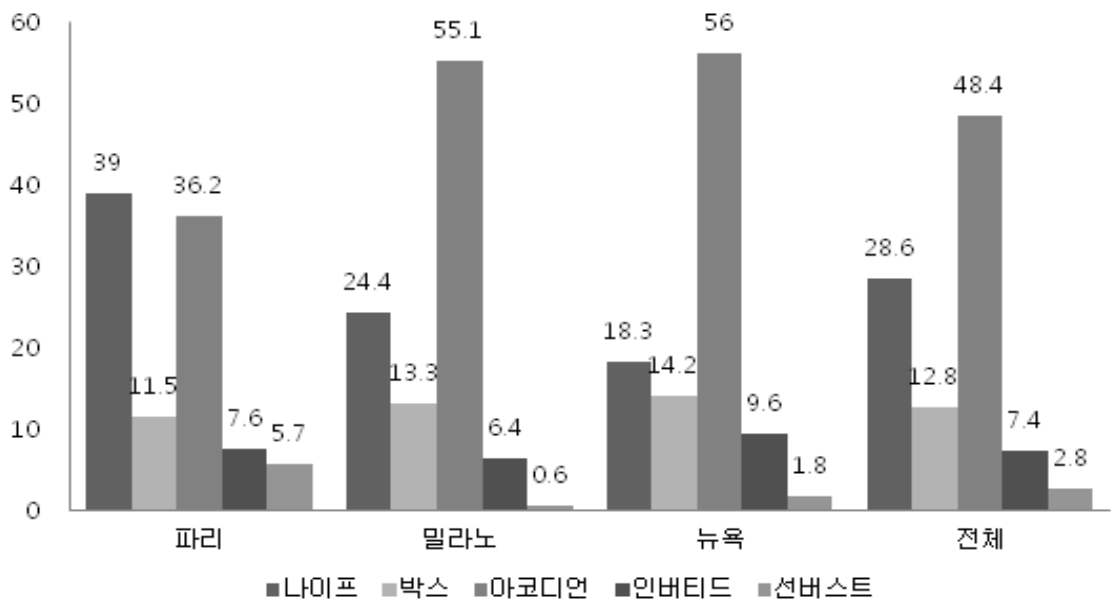

<그림 1> 3대 컬렉션에 나타난 플리츠 유형별 발생빈도율

전체적으로는 아코디언 플리츠가 583(48.4\%)로 가장 많이 사용되었고 그 다음은 나이프 $344(28.6 \%)$, 박스 $154(12.8 \%)$, 인버트드 $89(7.4 \%)$, 그리고 선버스트 $34(2.8 \%)$ 의 순으로 나타났으며, 3 개 도시 모두에서 5 가지 유형의 플리츠가 나타나, 도시별로 사용된 플리츠의 발생 유형에는 차이가 없 었다. 그러나 컬렉션에 따라 플리츠 유형별 발생빈 도율에는 차이를 보이고 있었는데, 발생양상의 차이 를 살펴보기 위해 <표 4>의 결과를 그래프로 나타 내어 살펴보았다.〈그림 1>

<그림 1>에서 보면 밀라노와 뉴욕은 아코디언플 리츠가 가장 많이 제시되고 있고 그 다음은 나이 프, 바스, 인버티드, 선버스트 순으로 나타났으며 빈 도율의 차이도 유사한 양상을 보이고 있다. 그러나 파리는 나이프와 아코디언 플리츠가 유사한 정도로
많이 사용되고 있었고, 그 다음은 다른 도시와 동일 한 순으로 나타났으며 선버스트 플리츠의 경우 다른 걸렉션보다는 다소 높은 비율로 나타났으나 이는 2010년 S/S시즌 스텔라 매카트니 컬렉션에서만 8개 의 선버스트 플리츠가 사용되었기 때문으로, 이를 제외하면 다른 도시와 커다란 차이가 있다고 보기 는 어렵다. 이처럼 컬렉션 도시별로 플리츠 유형의 발생양상에는 다소의 차이가 나타났다.

\section{2. 파리, 밀란 뉴욕 컬렉션에 나타난 플리츠 유형별 디자인의 조형적 특성}

1) 선의 두께를 중심으로 본 플리츠 유형별 특징

선의 두께를 중심으로 본 플리츠 유형별 특징을 살펴본 결과 플리츠 디자인에 사용된 소재는 얇은 
두께가 573개(47.6\%)로 가장 많이 사용되었고, 그 다음은 중간 두께 530개(44.0\%), 두꺼운 소재 사용 101 개(8.4\%)의 순으로 나타났다.<표 5>

이처럼 얇은 두께의 선이 가장 높게 나타난 이유 는 총 1204 개의 총 플리츠 디자인들 중 아코디언 플리츠에서만 455 개(37.8\%)의 얇은 소재가 사용되 었기 때문으로 플리츠 유형별로 사용된 선의 두께에 는 차이가 있는 것을 알 수 있다. 즉, 나이프 플리 츠는 중간 두께 254개(73.8\%), 얇은 두께 60개 (17.4\%), 두꺼운 두)ㅔㅔ 30개(8.7\%)로 나타났으며, 박 스 플리츠는 중간 두께 101개(65.6\%), 두꺼운 두께 30 개(19.5\%), 얇은 두께 23개(14.9\%) 순이었다. 아 코디언 플리츠는 얇은 두)ㅔㅔ 455개(78\%), 중간 두께 120 개(20.6\%), 두꺼운 두께 8개(1.4\%)의 순이며, 인버티드 플리츠는 중간 두께 42개(47.2\%), 두꺼운 두께 33개(37.1\%), 얇은 두께 14 개(15.7\%)의 순으 로, 마지막에 선버스트 플리츠는 얇은 두께 21 개 (61.2\%)와 중간 두)ㅔㅔ 13개(31.8\%)로 나타났으며 두 꺼운 두께의 플리츠 선은 나타나지 않았다. 이와같 은 결과를 종합해보면, 아코디언 플리츠와 선버스트 플리츠에는 얇은 두께의 소재들이 상당히 높은 비율 로 가장 많이 사용된 반면, 나이프 플리츠, 박스 플 리츠, 인버티드 플리츠는 중간 두께의 소재들을 가 장 많이 사용하고 있다는 공통점이 나타났다.

이러한 양적 결과를 중심으로 플리츠 유형별 선의 조형적 특성을 질적으로 살펴본 결과, 패션 디자인 에 얇은 두께의 소재를 사용한 경우는 우미하고 여
성스러워 보이게 하는 효과가 있으며, 반대로 두꺼 운 소재를 사용하는 경우에는 확실하고 남성다운 분 위기가 더욱 강조되고 있었다. 이처럼 본 연구에 나 타난 플리츠 디자인의 경우 플리츠 유형별 특성에 따라 서로 다른 두께의 소재를 사용함으로써 다양한 효과를 연출해 내고 있었다.

유형별로 보다 구체적으로 살펴보면, 아코디언 플 리츠와 선버스트 플리츠의 경우는 얇은 두께의 부드 럽고 여성적인 소재에 폴드면들이 매우 좁고 정교한 디자인들이 주를 이루고 있음으로 여성적이고, 우아 한 디자인들이 많이 나타나 있었다.<사진 1> 그러나 동일한 얇은 두께의 소재들 중에서도 빳빳한 경우에 는 부드럽고 얇은 소재보다는 다소 경쾌하고 젊은 이미지를 나타내도록 디자인 되어 있었다.<사진 2> 아코디언 플리츠는 중간 두께의 소재를 사용한 디 자인들도 비교적 많이 나타났는데, 얇은 소재가 사 용된 디자인들 보다는 주름의 폭이 좁은 것에서 보 다 넓은 것에 이르기까지 비교적 다양한 유형들로 나타났다. 주름의 폭이 넓어질수록 보다 편안하고 자유로운 느낌을 주었다.<사진 3> 또한 주름의 폭이 동일하거나 유사한 경우에도 사용된 소재의 유형에 따라 시각적 효과도 달라졌는데, 실크처럼 부드럽고 매끈한 소재를 사용한 경우에는 보다 우아한 이미지 가 강조된 반면, 니트 조직이나 보다 캐주얼한 면직 물, 모직류의 소재가 사용된 경우 보다 활동적이고 캐주얼한 효과를 나타내고 있었다.<사진 4>

<표 5> 플리츠 유형에 따른 선의 두께별 발생빈도 및 빈도율

\begin{tabular}{c|c|c|c|c}
\hline \hline 펄리츠유희읭 두)케 & 두꺼운 & 중간 & 얇은 & 전체 \\
\hline \multirow{2}{*}{ 나이프 } & $30(8.7 \%)$ & $254(73.8 \%)$ & $60(17.4 \%)$ & $344(100.0 \%)$ \\
& $29.7 \%$ & $49.1 \%$ & $10.9 \%$ & $29.4 \%$ \\
\hline \multirow{2}{*}{ 박스 } & $30(19.5 \%)$ & $101(65.6 \%)$ & $23(14.9 \%)$ & $154(100.0 \%)$ \\
& $29.7 \%$ & $19.5 \%$ & $4.2 \%$ & $13.2 \%$ \\
\hline \multirow{2}{*}{ 아코디언 } & $8(1.4 \%)$ & $120(20.6 \%)$ & $455(78.0 \%)$ & $583(100.0 \%)$ \\
& $7.9 \%$ & $23.2 \%$ & $82.4 \%$ & $49.8 \%$ \\
\hline \multirow{2}{*}{ 인버티드 } & $33(37.1 \%)$ & $42(47.2 \%)$ & $14(15.7 \%)$ & $89(100.0 \%)$ \\
& $32.7 \%$ & $8.1 \%$ & $2.5 \%$ & $7.6 \%$ \\
\hline \multirow{2}{*}{ 선버스트 } & $0(0.0 \%)$ & $13(31.8 \%)$ & $21(61.2 \%)$ & $34(100 \%)$ \\
& $0.0 \%$ & $2.5 \%$ & $3.7 \%$ & $2.8 \%$ \\
\hline \multirow{2}{*}{ 전체 } & $101(8.4 \%)$ & $530(44.0 \%)$ & $573(47.6 \%)$ & $1204(100.0 \%)$ \\
& $100.0 \%$ & $100.0 \%$ & $100.0 \%$ & $100.0 \%$ \\
\hline \hline
\end{tabular}


선버스트 플리츠의 경우는 13 개의 중간 두께 중 8개가 2010년S/S 스텔라 매카트니 컬렉션에서 나타 났는데, 플리츠의 끝단을 다른 디자인에서처럼 폴드 면이 자연스럽게 퍼지도록 하지 않고 원주형으로 편 편하게 퍼지도록 하는 인위적인 터치를 더하여 새로 운 느낌의 선버스트 플리츠 디자인을 선보이고 있었 다.〈사진 5>

나이프, 박스, 인버티드 플리츠는 중간 두께의 소 재를 가장 많이 사용하였다. 유형별로 살펴보면, 중 간 두께를 사용한 박스 플리츠는 전면의 플리츠 박 스가 주로 4 6개 정도로 나타났고, 사용된 소재의 부드러운 정도에 따라 다소 다른 느낌을 보여주었으 나, 주로 아래 폭이 넓은 $\mathrm{A}$-라인 실루엣에 젊고 경 쾌한 스쿨룩과 같은 다양한 디자인의 형태로 남성적 혹은 중성적인 활달함으로 보여주고 있었다.<사진 6> 인버티드 플리츠는 주로 앞 중심에 한 개 혹은 양쪽에 두 개의 슬리트가 있는 형태로 나타났는데, 대체로 클래식하면서 단정하고 보수적인 여성적 이 미지로 표현되고 있었다.<사진 7> 나이프 플리츠의 경우는 플리츠의 폭이 아주 좁은 것에서 비교적 넓 은 것에 이르기까지 다양하였고<사진 8>, 의복디자 인 전체 혹은 디테일이나 의복의 일부분에만 사용되 기도 하였으며<사진 9>, 다양한 유형의 텍스츄어로, 페미닌한 스타일에서 아방가르드한 스타일에 이르기 까지 다양한 스타일에 적용되어 나타나 가장 다양한 디자인을 보여주고 있었다.<사진 10> 전반적으로는 주름 폭이 넓어질수록 더욱 남성적이고 견고한 이미
지가 증가하였고 평범해 보이기 쉬운 나이프 플리츠 는 아방가르드한 스타일에 비대칭형으로 적용되면서 매우 흥미롭고 다양한 디자인을 연출해 내고 있었 다.〈사진 11>

두꺼운 소재를 사용한 박스와 인버티드 플리츠는 소재의 부드러움 정도에 따라 다소 차이는 있었으나 중간 두께의 경우와 근본적인 차이가 그리 많지 않 은 것으로 나타났다. 얇은 소재를 사용한 나이프 플 리츠는 주름의 폭이 좁은 경우에는 아코디언 플리츠 의 특성과 커다란 차이를 보이지 않고 있었다.<사진 12>

\section{2) 선의 연속성을 중심으로 본 플리츠 유형별 디자인의 특성}

플리츠 유형별 선의 연속성과 불연속성을 살펴본 결과 전체적으로는 연속적인 선이 952개(79.1\%)로 주도적으로 많이 사용되었고, 불연속 선은 252 개 (20.9\%)로 나타났다.〈표 6>

플리츠 유형별로 보면 선버스트 플리츠를 제외한 나머지 플리츠 유형에서 연속적인 선들이 높은 비율 로 나타났다. 구체적으로 언급해 보면, 나이프 플리 츠의 경우는 연속적 306 개(89.0\%), 불연속적 38 개 (11.0\%)로, 박스 플리츠와 인버티드 플리츠는 각각 연속적인 선만 154 개(100.0\%)와 89 개(100.0\%)로 나타났다. 아코디언 플리츠는 연속적 401개(68.8\%), 불연속적 182 개(31.2\%)로 나타났고, 선버스트 플리

<표 6> 플리츠 유형별 연속적·불연속적 선의 발생빈도 및 빈도율

\begin{tabular}{c|c|c|c}
\hline \hline 역속성 여부 & 연속적 & 불연속 & 전체 \\
플리츠유형 & $306(89.0 \%)$ & $38(11.0 \%)$ & $344(100.0 \%)$ \\
나이프 & $32.1 \%$ & $15.1 \%$ & $29.4 \%$ \\
\hline 박스 & $154(100.0 \%)$ & $0(0.0 \%)$ & $154(100.0 \%)$ \\
& $16.2 \%$ & $0.0 \%$ & $13.2 \%$ \\
\hline \multirow{2}{*}{ 아코디언 } & $401(68.8 \%)$ & $182(31.2 \%)$ & $583(100.0 \%)$ \\
& $42.1 \%$ & $72.2 \%$ & $49.8 \%$ \\
\hline 인버티드 & $89(100.0 \%)$ & $0(0.0 \%)$ & $89(100.0 \%)$ \\
선버스트 & $9.3 \%$ & $0.0 \%$ & $3.6 \%$ \\
\hline \multirow{2}{*}{ 전체 } & $2(5.9 \%)$ & $32(94.1 \%)$ & $2.8 \%$ \\
\hline \hline & $0.2 \%$ & $12.7 \%$ & $1204(100.0 \%)$ \\
& $952(79.1 \%)$ & $252(20.9 \%)$ & $100.0 \%$ \\
\hline
\end{tabular}


츠 연속적 2개(5.9\%), 불연속적 32개(94.1\%)로 나 타났다. 즉, 선버스트 플리츠에서만 불연속적인 선 이 주도적으로 사용되었고 나머지 유형들은 연속적 인 선을 이용한 디자인들이 상당히 높은 비율로 나 타났다. 또한 박스 플리츠와 인버티드 플리츠에서는 불연속적인 선이 전혀 사용되지 않았으나, 아코디언 플리츠와 나이프 플리츠에서는 $182(31.2 \%)$ 와 38 개 $(11.0 \%)$ 의 불연속선이 나타났다.

이러한 결과를 중심으로 선의 연속성과 관련된 특 성을 보다 자세하게 파악하기 위하여 디자인들을 질 적으로 분석한 결과, 연속적인 선이 사용된 경우 일 반적인 플리츠 디자인들과 크게 다른 특성은 나타나 지 않았다. 그러나, 본 연구의 주된 목적은 플리츠 유형별 디자인의 특성을 파악하기 위한 것임으로, 낮은 빈도율로 나타났으나 디자인의 변화가 보다 다 양한 비연속적인 선을 중심으로 플리츠 유형별 디자 인의 조형적 특성을 살펴보았다. 그 결과, 비연속적 인 선을 사용한 플리츠 디자인의 경우는, 플리츠를 여러 층으로 레이어드 시키는 형태를 주로 사용한 것으로 나타났다. 예를 들어, <사진 13>의 선버스트 플리츠 경우처럼 꽃잎들을 겹쳐둔 것 같은 형태를 이루면서 레이어드 된 플리츠들이 매우 리드미컬하 면서도 생동감있고, 경쾌하고 여성적인 이미지를 표 출해내고 있었다. 이처럼 레이어드 된 형태는 레이 어 한 단씩 선들이 끊겨져 있으나 그 다음 단에도 동일한 플리츠의 유형이 반복됨으로서 심리적으로는 시작에서부터 끝나는 지점까지의 경로를 유추해 낼
수 있음으로 인하여 그 리듬감이 더욱 다이내믹하게 느껴진다. <사진 14> 이러한 연구결과는 불연속적 인 선은 캐주얼하고, 스포티하며, 쾌활한 심리적 효 과를 주고 선이 끊겨진 경우에라도 그 궤도는 암시 ${ }^{35)}$ 한다는 선행 문헌의 내용을 지지하는 것이다.

그 밖에는 허리나 가슴 밑의 요크선 혹은 스커트 다트 부분 등과 같은 의복 구성선 위치에서 선을 일 시 정지 시키거나 장식 등을 넣어줌으로써 플리츠 디자인에 다양한 변화를 시도하는 디자인들로 나타 났다.<사진 15>

\section{3) 선의 길이를 중심으로 본 플리츠 유형별 디자인의 특성}

플리츠 유형별 디자인의 조형적 특성을 선의 길이 를 중심으로 살펴본 결과 긴 길이가 671 개(55.7\%), 짧은 길이가 533개(44.3\%)로 나타났다.〈표 7>

플리츠 유형별로 살펴보면 나이프, 아코디언, 선 버스트 플리츠는 긴 길이가, 박스와 인버티드 플리 츠는 짧은 길이가 더 많이 사용되었다. 구체적으로 는, 나이프 플리츠는 길다 176 개(51.3\%)와 짧다 168 개(48.8\%), 박스 플리츠는 짧다 88 개(57.1\%)와 길다 66 개(42.9\%), 아코디언 플리츠는 길다 365 개 $(62.6 \%)$ 와 짧다 218 개(37.4\%)의 빈도와 빈도율을 나타냈다. 인버티드 플리츠는 길다 48 개(53.9\%)와 짧다 41 개 $(46.1 \%)$ 이었으며, 선버스트 플리츠는 길 다 23 개(67.6\%)와 짧다 11 개(32.4\%)로 나타났다.

<표 7> 플리츠 유형별 선의 길이의 발생빈도 및 빈도율

\begin{tabular}{c|c|c|c}
\hline 길이 & 길다 & 짧다 & 전체 \\
\hline \multirow{2}{*}{ 나이프 } & $176(51.2 \%)$ & $168(48.8 \%)$ & $344(100.0 \%)$ \\
& $26.2 \%$ & $31.5 \%$ & $29.4 \%$ \\
\hline \multirow{2}{*}{ 박스 } & $66(42.9 \%)$ & $88(57.1 \%)$ & $154(100.0 \%)$ \\
\hline \multirow{2}{*}{ 아코디언 } & $9.8 \%$ & $16.5 \%$ & $13.2 \%$ \\
\hline \multirow{2}{*}{ 인버티드 } & $365(62.6 \%)$ & $218(37.4 \%)$ & $583(100.0 \%)$ \\
선버스트 & $54.4 \%$ & $40.9 \%$ & $49.8 \%$ \\
\hline \multirow{2}{*}{ 전체 } & $41(46.1 \%)$ & $48(53.9 \%)$ & $89(100.0 \%)$ \\
& $6.1 \%$ & $9.0 \%$ & $34(100 \%)$ \\
& $23(67.6 \%)$ & $11(32.4 \%)$ & $2.8 \%$ \\
\hline \hline
\end{tabular}


이러한 결과로 플리츠에 사용된 선의 길이는 플리 츠 유형별로 다르며, 긴 길이와 짧은 길이의 선이 사용된 정도 차이도 유형별로 각각 다르다는 것을 알 수 있다.

플리츠 유형별로 사용된 선의 길이에 따라 어떠한 의복 아이템에 사용되었는가를 살펴본 결과, 나이프, 아코디언, 선버스트 플리츠의 경우 긴 길이의 원피 스나 긴 스커트 등에 주로 나타났고, 짧은 길이는 짧은 스커트나 레이어드가 디자인 요소로 사용된 부 분에서 많이 나타났다. 박스와 인버티드 플리츠는 대부분 스커트나 원피스의 허리선 아래쪽에 주로 나 타났고, 긴 길이는 긴 상의, 긴 스커트나 긴 원피스 의 허리선 아래 부분에 사용되었다. 플리츠는 길이 뿐 만이 아니라 위치, 방향, 배치 방법, 적용 범위 등이 매우 다양하게 사용되어 흥미로운 결과를 보였 다.

\section{4) 방향을 중심으로 본 플리츠 유형별 디자인의 특성}

플리츠 유형별 선의 방향을 살펴본 결과 수직선 1145 개(95.1\%), 혼합 40개(3.3\%), 사선 17개(1.4\%) 의 순으로 나타났으며 수평선은 나타나지 않았다. <표 8>

<표 8>의 결과를 플리츠 유형별 살펴보면 나이프 플리츠는 수직 315개(91.6\%), 혼합 15개(4.4\%), 사 선 12 개(3.5\%)의 순으로, 아코디언 플리츠는 수직
개(2.9\%)의554개(9.5.0\%), 혼합 25개(4.3\%), 사선 4개(0.7\%), 선버스트 플리츠에서는 수직 33 개 (97.1\%), 혼합 1 순으로 나타났다. 한편 박스 플리 츠와 인버티드 플리츠는 각각 수직154개(100\%), 수 직 89 개(100\%)로 한개 방향의 선만이 나타났다.

종합해보면, 거의 모든 경우 플리츠는 수직선이 주도적인 것으로 나타나 플리츠는 주로 수직선에 해 당한다미는 선행연구의 내용을 지지하고 있다.

그러나 플리츠 디자인의 특성을 살펴보기 위한 본 연구의 주된 목적으로 볼 때, 일반적인 수직선의 플 리츠 디자인을 살펴보기 보다는, 낮은 비율로 나타 난 사선이나 혼합형의 경우를 면밀히 살펴보는 것이 더 적절할 것으로 판단되었음으로 이러한 유형들을 중심으로 디자인의 특성을 질적으로 살펴본 결과 다 음과 같았다.;

1.사선을 이용한 플리츠 디자인의 특성은 주로 가 볍고 율동감을 주며, 의복 디자인의 작은 부분에 악 센트를 주거나 장식적인 용도로 사용되고 있었다. 이러한 사선의 플리츠는 수평선과 수직선이 주를 이 루고 있는 의복 디자인에 방향의 전환에서 오는 신 선한 변화를 느끼게 하고, 두 개 이상의 반복되는 레이어드 디자인의 경우 리듬감을 더욱 강조하여 시 각적 흥미를 유발하도록 하였다.

2. 사선과 혼합선을 이용한 플리츠 디자인은 아래 와 같은 특성으로 요약될 수 있었다.

(1) 한 디자인 내에서는 동일한 플리츠의 유형과 동일한 주름의 폭을 사용하여 반복의 원리를 적용한

<표 8> 플리츠 유형별 수직·수평·사선·혼합 선의 발생빈도 및 빈도율

\begin{tabular}{c|c|c|c|c}
\hline \hline 선의유형 & 수직 & 사선 & 혼합 & 전체 \\
\hline 플리츠유형 & $315(91.6 \%)$ & $14(4.0 \%)$ & $15(4.4 \%)$ & $344(100.0 \%)$ \\
나이프 & $28.3 \%$ & $73.70 \%$ & $37.5 \%$ & $29.4 \%$ \\
\hline \multirow{2}{*}{ 박스 } & $154(100.0 \%)$ & $0(0.0 \%)$ & $0(0.0 \%)$ & $154(100.0 \%)$ \\
& $13.8 \%$ & $0.0 \%$ & $0.0 \%$ & $13.2 \%$ \\
\hline \multirow{2}{*}{ 아코디언 } & $554(95.0 \%)$ & $4(0.7 \%)$ & $25(4.3 \%)$ & $583(100.0 \%)$ \\
& $49.8 \%$ & $25.0 \%$ & $62.5 \%$ & $49.8 \%$ \\
\hline \multirow{2}{*}{ 인버티드 } & $89(100.0 \%)$ & $0(0.0 \%)$ & $0(0.0 \%)$ & $89(100.0 \%)$ \\
\multirow{2}{*}{ 선버스트 } & $8.0 \%$ & $0.0 \%$ & $0.0 \%$ & $7.6 \%$ \\
\hline \multirow{2}{*}{ 전체 } & $33(97.1 \%)$ & $1(2.9 \%)$ & $0(0.0 \%)$ & $34(100.0 \%)$ \\
& $2.9 \%$ & $5.9 \%$ & $0.0 \%$ & $2.8 \%$ \\
\hline \hline
\end{tabular}


디자인들이 주를 이루고 있었다.

(2) 사선의 방향은 한 방향만을 사용한 경우가 대 부분이었으나 좌우 대칭으로 두 개를 배치하거나<사 진 16> 혹은 다양한 사선의 방향으로 여러개를 반 복시키기도 하고<사진 17>, 또한 방사선 형태로 배 치<사진 18>하는 등 흥미로운 플리츠 디자인의 응 용을 보여주고 있었다. 반복의 단위가 작고 숫자가 많아질수록 디자인에서 느껴지는 리듬감은 증가하고 있었다.

(3) 혼합선의 경우는 사선에 비해 비교적 변화가 적은 것으로 나타났는데, 주로 사선을 한번이나 두 번 정도 반복시키고 직선을 한번 정도 반복하는 경 우가 대부분이었다.<사진 19>

(4) 사선의 플리츠는 원피스나 스커트와 같은 의 복 아이템 전면에 사용되기도 하고<사진 21> 어깨, 가슴이나 소매 부분 등에 일부 사용되거나 장식적 디테일로 사용되기도 하여<사진 21> 다양하게 적용 되고 있었으나, 혼합형의 경우는 대부분이 의복 아 이템 전면에 사용되고 있었다. <사진 22>

\section{V. 결 론}

2009년F/W 2012년S/S시즌 까지 『Collection $\mathrm{s}$ 지에 나타난 파리, 밀라노, 뉴욕 3대 컬렉션을 중심으로 현대 패션에 나타난 플리츠 유형이 무엇이 며 유형별 디자인의 조형적 특성을 파악한 결과를 요약하면 다음과 같았다.

첫째, 연구에 포함된 총 디자인의 수는 23,865 개 이었으며 이 중 플리츠 디자인은 1,027(5.05\%)로 비교적 높은 비율로 나타났다. 컬렉션별로는 밀라노 에서 가장 많이(5.8\%) 제시하였고 파리와 뉴욕은 동 일한 비율(4.6\%)로 나타났다.

3대 컬렉션에 사용된 주된 플리츠 유형은 5개로, 아코디언 플리츠, 나이프 플리츠, 박스 플리츠, 인버 티드 플리츠, 선버스트 플리츠 순으로 나타났다. 컬 렉션별로 사용된 플리츠의 유형은 모두 동일하였으 나, 플리츠 유형의 발생빈도율과 발생 양상은 컬렉 션별로 서로 다르게 나타났다. 또한, 플리츠 유형별 발생 순위도 미약하나마 도시별로 차이를 보이고 있
었는데, 이러한 도시별 플리츠 유형의 발생 양상과 사용정도의 차이는 컬렉션별 고유한 특성과 무관하 지 않을 것으로 판단되었다.

둘째, 플리츠 디자인의 조형적 특징을 살펴보기 위하여 플리츠에 사용된 소재에 의한 선의 두께와 디자인에 사용된 플리츠 선의 연속성 여부와 길이, 그리고 선의 방향을 중심으로 살펴본 결과 다음과 같았다.

(1)전반적으로는 얇은 소재가 가장 많이 사용되었 으며 중간두께 그리고 두꺼운 순으로 나타났다. 플 리츠 유형별로 아코디언 플리츠와 선버스트 플리츠 에는 얇은 두께의 소재들을 주로 사용하여 폴드면들 이 좁고 가는 형태의 정교한 디자인들이 주를 이루 고 있었다. 반면, 나이프, 박스, 인버티드 플리츠에 는 중간두께의 소재들을 많이 사용하는 공통점은 있 었으나, 플리츠의 폭의 넓이와 수, 소재의 유연성의 정도와 텍스츄어의 특성에 따라 서로 다른 이미지를 표출해 내고 있었다. 이처럼 플리츠 유형에 따라 사 용된 소재의 두께에는 다소 차이를 보이고 있었다. 유형별 디자인을 살펴보면, 박스플리츠는 전면에 4 6개 정도의 박스를 지닌 아래 폭이 넓은 $\mathrm{A}$ 라인 의 스쿨룩의 형태로 젊고 활달한 남성적 혹은 중성 적 이미지를 표출해 내고 있었다. 인버티드 플리츠 는 주로 앞중심에 하나의 주름선이나 양측에 두 개 의 슬리트가 있는 형태로, 클래식하고 단정하거나 보수적인 여성적 이미지로 표현되고 있었다. 나이프 플리츠의 경우는 가장 다양하게 나타났는데, 좁은 것에서 비교적 넓은 간격의 플리츠 폭과 의복 디자 인의 전면 혹은 일부에 사용되는 다양한 적용범위, 그리고 부드러운 것에서 빳빳한 것에 이르는 다양한 유형의 소재, 페미닌한 것에서 아방가르드한 것에 이르는 다양한 패션 스타일에 적용되어 평범해 보이 기 쉬운 나이프 플리츠는 매우 흥미롭고 다양한 선 의 효과를 연출해 내고 있었다.

두꺼운 소재를 사용한 박스와 인버티드 플리츠는 소재의 부드러움 정도에 따라 다소 차이는 있었으나 중간 두께의 경우와 근본적인 차이가 그리 많지 않 은 것으로 나타났으며, 얇은 소재를 사용한 나이프 플리츠는 주름의 폭이 좁은 경우에는 아코디언 플리 츠의 특성과 커다란 차이를 보이지 않고 있었다. 
이처럼, 플리츠는 사용된 소재에 의한 선의 두께뿐 만 아니라 플리츠의 수, 간격, 소재의 유연성 정도 와 텍스츄어의 유형에 따라 시각적 효과에 영향을 받는 것을 알 수 있다.

(2) 플리츠 디자인에 사용된 선들은 선버스트 플 리츠를 제외하면 연속적인 것이 주도적인 것으로 나 타났으나, 특별히 주목할 만한 특성은 나타나지 않 았다. 그러므로 비연속적인 선을 사용한 경우를 중 심으로 플리츠 유형별 디자인의 특성을 살펴 본 결 과, 비연속선은 플리츠를 여러 층으로 레이어드 시 키는 형태로 주로 나타났으며, 그 밖에는 허리나 가 슴 밑의 요크선 혹은 스커트 다트 부분 등과 같은 의복 구성선 위치에서 선을 일시 정지 시키거나 장 식 등을 넣어줌으로써 플리츠 디자인에 다양한 변화 를 시도하는 형태로 나타났다.

(3) 길이를 중심으로 살펴본 결과 전체적으로는 긴 길이가 사용된 경우가 더 많았으나, 플리츠 유형 에 따라 긴 길이와 짧은 길이의 선이 사용된 정도 차이도 각각 다른 것으로 나타났다. 즉, 나이프, 아 코디언, 선버스트 플리츠는 긴 길이가, 박스와 인버 티드 플리츠는 짧은 길이가 더 많이 사용되었다.

플리츠 유형별로 선의 길이에 따라 어떠한 의복 아이템 디자인에 적용되었는가를 살펴본 결과, 나이 프, 아코디언, 선버스트 플리츠의 경우는 긴 길이의 원피스나 긴 스커트 등에 주로 나타났고, 짧은 길이 는 짧은 스커트나 레이어드를 사용한 부분에서 많이 나타났다. 박스와 인버티드 플리츠는 대부분 스커트 나 원피스의 허리선 아래쪽에 주로 짧은 길이로 나 타났고, 긴 길이는 긴 상의, 긴 스커트나 긴 원피스 의 허리선 아래 부분에 사용되었다.

긴 길이의 선들은 대체로 우아하고 길이를 강조하며 때로는 움직일 때 스포티한 느낌을 보여주는 반면, 짧은 선들은 보다 경쾌하고 활발한 이미지를 보여주 고 있었다.

(4) 선의 방향을 중심으로 살펴본 결과 수직선이 압도적으로 많이 나타났으며, 그 다음은 혼합형, 그 리고 사선의 순으로 나타났다. 일반적인 수직선의 플리츠 디자인보다는 사선과 혼합형의 경우가 더 흥 미 있는 결과를 보이고 있었음으로 이를 중심으로 플리츠 디자인의 특성을 살펴본 결과 다음과 같이
세가지 특성으로 요약되었다.

(1) 한 디자인 내에서는 동일한 플리츠의 유형과 동일한 주름의 폭을 사용하여 반복의 원리를 적용한 디자인들이 주를 이루고 있었다.

(2) 사선의 방향은 한 방향만을 사용한 경우가 대 부분이었으나, 좌우 대칭으로 두 개를 배치하거나 혹은 다양한 사선의 방향으로 여러 개를 반복시키기 도 하고, 또한 방사선 형태로 배치하는 등 흥미로운 플리츠 디자인의 활용을 보여주고 있었다. (3) 수평 선과 수직선이 주를 이루고 있는 의복 디자인에서 사선의 플리츠는 방향의 전환에서 오는 신선한 변화 를 느끼게 하고, 두 개 이상의 반복되는 레이어드 디자인의 경우 숫자가 많아질수록 디자인에서 느껴 지는 리듬감 리듬감을 더욱 강조하여 시각적 흥미를 유발하도록 하였다.

혼합선의 경우는 사선에 비해 비교적 변화가 적은 것으로 나타났는데, 주로 사선을 한번이나 두 번 정 도 반복시키고 직선을 한번 정도 반복하는 경우가 대부분이었다.

이와 같은 결과를 결론적으로 언급해 보면 다음과 같다.

1. 최근 패션의 핫 트랜드로 주목받고 있는 플리 츠는, 연구결과 현재까지는 다양한 플리츠의 유형들 이 소개되었다고 보기는 어려우며, 유형별 형태 자 체도 일부 새로운 형태로의 변화를 시도한 실례가 없는 것은 아니나 대부분은 과거에 나타난 형태에서 크게 벗어나지 않고 있었다. 그러므로 보다 다양한 플리츠 유형들을 패션디자인에 적극적으로 활용함으 로서 새로운 디자인 개발을 시도할 수 있을 것이다.

2. 플리츠 디자인은 사용되는 소재의 두께를 비롯 하여 플리츠 선의 길이, 연속성, 방향 등과 밀접한 관계를 가지고 다양한 방식으로 적용되어 나타났으 며, 이 밖에도 플리츠 폭의 넓이와 수, 의복디자인 에 사용된 위치와 범위에 따라 다양한 디자인의 변 화를 제시해 주고 있었다. 그러므로 향후 플리츠를 디자인에 활용하기 위해서는 이러한 다양한 측면들 에 대한 충분한 고려가 선행되어야 할 것이다.

3. 앞에서 언급된 플리츠 디자인과 밀접한 관계가 있는 디자인의 요소와 원리들은 3 대 컬렉션에 참여 
하는 디자이너들 나름대로의 창의적 아이디어와 발 상의 전환 등을 거쳐 다양한 의상 아이템에 새로운 형태나 감각으로 적용됨으로서, 과거의 형태를 지녔 으나 현대적 감각을 지닌 새로운 모습의 새로운 플 리츠로 탈바꿈하여 현대 패션에 나타나고 있음을 알 수 있다.

구체적으로 살펴보면, 아코디언, 선버스트, 박스, 인버티드 플리츠의 경우는 각 유형별로는 어느 정도 참신하고 새로운 플리츠 디자인의 사용방식이 제시 되기는 하였으나, 아코디언과 선버스트 플리츠의 경우는 거의 동일한 유형으로 나타났으며, 박스와 인버티드 플리츠의 경우에는 플리츠 형태 변화와 적 용방식과 적용범위 등의 차이가 그리 크게 두드러지 지 않았다. 그러나 나이프 플리츠는 좁은 것에서 비 교적 넓은 간격의 플리츠 폭의 사용, 다양한 의복
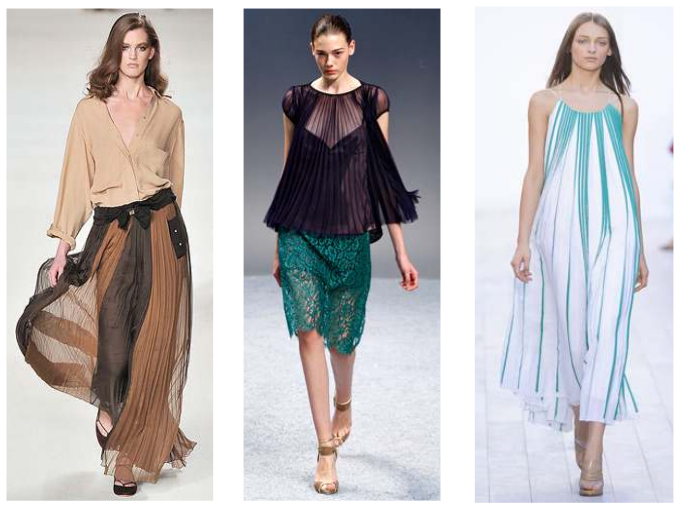

<사진 1>

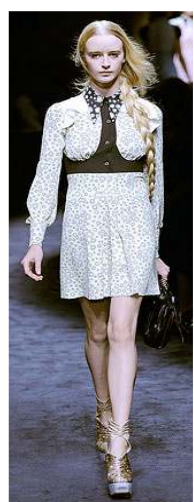

$<$ 사진 7>
<사진 2>

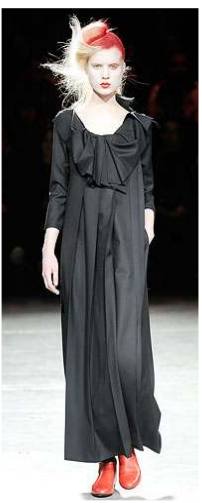

$<$ 사진 8>
<사진 3>

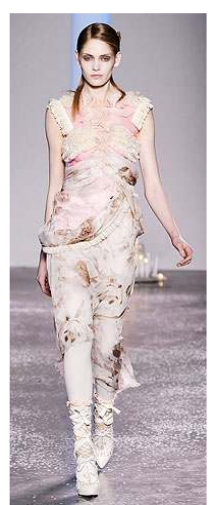

$<$ 사진 9>
아이템으로의 적용, 한 디자인 내에서의 전면 혹은 극히 일부의 사용 등에 의한 다양한 적용 범위와 위 치 선정, 다양한 유형의 소재 사용, 페미닌한 것에 서 아방가르드한 것에 이르는 다양한 패션 스타일에 적용되어 평범해 보이기 쉬운 나이프 플리츠는 매우 흥미롭고 새로운 모습을 연출해 내고 있음으로 인하 여 가장 주목할 만한 유형으로 판단되었다. 이처럼 평범한 것을 비범하거나 새로운 감각의 변화된 모 습으로 재창출해 내는 아이디어는 가장 기본적인 것 에서부터 시작될 수 있음을 보여주고 있는 실례라 할 수 있다.

본 연구의 결과는 플리츠 유형에 대한 보다 심도 있는 이해를 도모할 수 있으며 아울러 플리츠 유형 별 디자인의 새로운 아이디어의 개발에 필요한 자료 를 제공함으로써 보다 다양하고 새로운 플리츠 디자

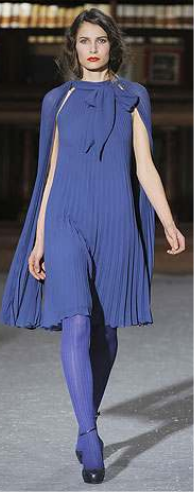

<사진 $4>$

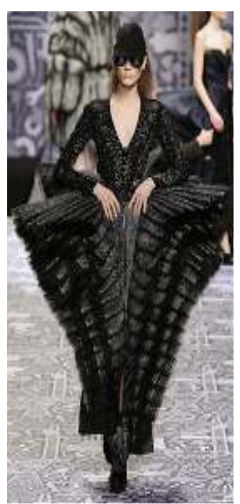

$<$ 사진 10>

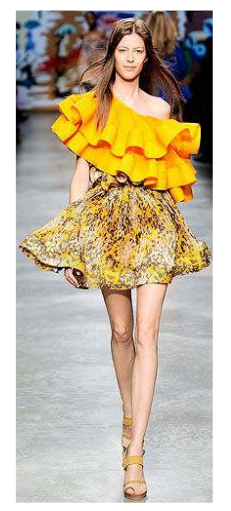

<사진 5>

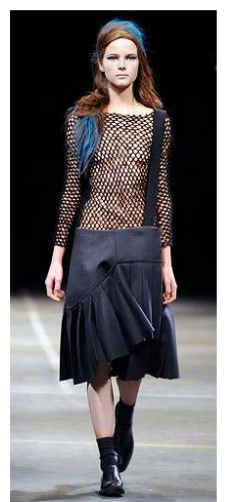

<사진 11>

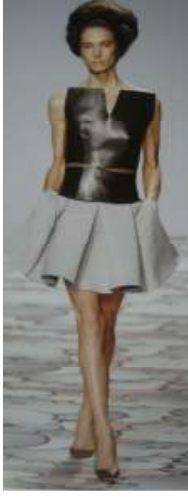

<사진 6>

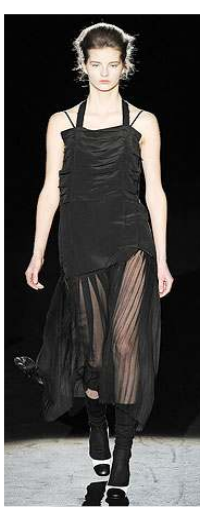

<사진 12> 


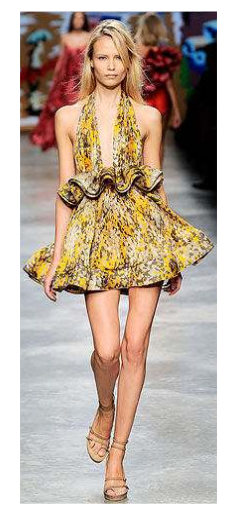

<사진 13>

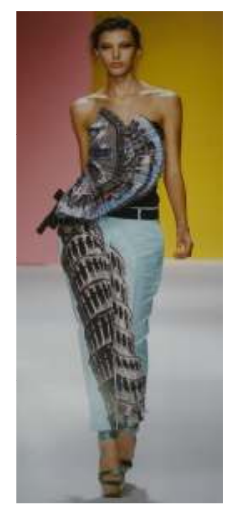

<사진 17>

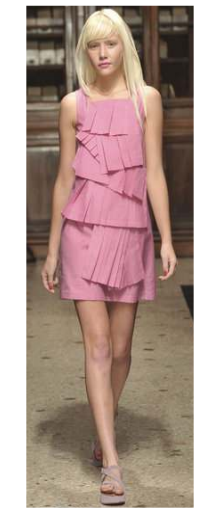

<사진 14>

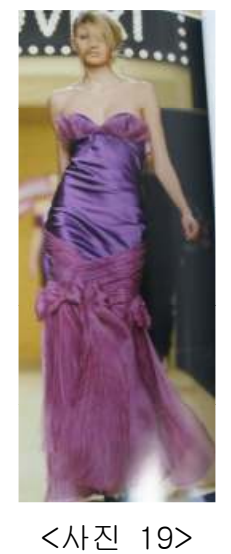

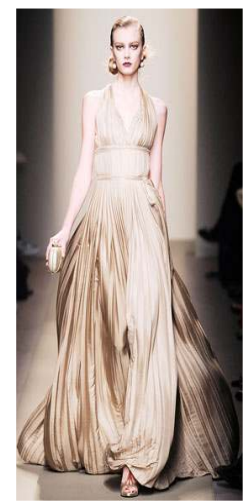

<사진 15>

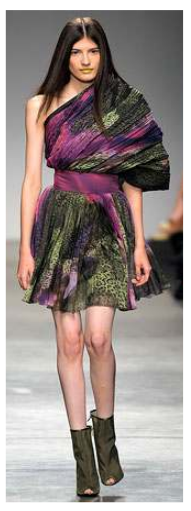

<사진 20>
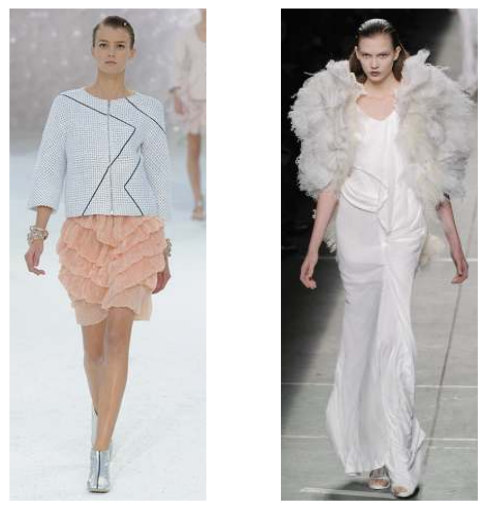

<사진 16>

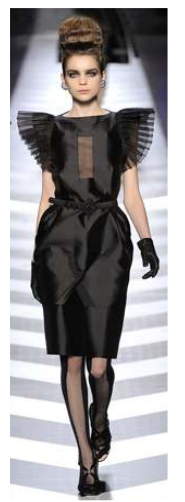

<사진 21>
<사진 17>

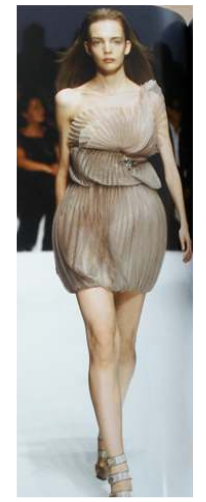

<사진 22>
인 아이디어 개발에 도움을 줄 수 있을 것으로 기대 된다.

\section{참고문헌}

1) 손영미, 이수현(2004), "플리츠기법을 응용한 패 션디자인 연구 -해체주의 패션을 중심으로-". 한국복식학회, 54(6), p.154.

2) "플리츠 스커트 전성시대 -please PLEATS-", 2010. 10. VOGUE, 10월호, 자료 검색일 2011,11,16, 자료출처 http://www.style.co.kr/ vogue/trend/trend_view.asp?menu_id=020402 00\&c_idx $=010105030001984$

3) Gini Stephens Frings(2001), Fashion : from concept to consumer. New Jersey:Prentice Hall Inc., p. 140.

4) Davis, Marian L. 저. 이화연, 손미영, 노희숙 역(1990), 복식의 시각디자인. 서울:경춘사. p.65.

5) 이경희, 이은령(2008), 패션 디자인 플러스 발 상. 서울:교문사, p.68.

6) 권은영(2004), "현대 텍스타일의 주름 표현에 관한 연구", 이화여자대학교 석사학위논문.

7) 나진주(2009), "플리츠기법을 이용한 섬유작품 연구", 숙명여자대학교 석사학위논문.

8) 양진숙(2004), "플리츠(pleats) 가공기법을 활용 한 섬유소재 디자인에 관한 연구", 한국색채학 회 , 18(3), pp.105-114.

9) 곽혜영(2000), "의상 디자인의 주름표현 연구", 
이화여자대학교 석사학위논문

10) 신윤미(1997), "복식 디자인에 표현된 주름에 관한 연구", 홍익대학교 석사학위논문.

11) 민경애, 원영옥(2002), "주름의 선을 이용한 의 상 디자인 연구", 한국패션디자인학회지, 2(2), pp.85-95.

12) 손영미, 이수현(2004), op.cit.

13) 이유경(1993), "주름의 조형성을 이용한 의상 디자인 연구 -플리츠와 러플을 중심으로-", 이 화여자대학교 석사학위논문.

14) 이수현(2003), "플리츠기법을 이용한 의상디자 인 연구", 조선대학교 석사학위논문.

15) 김정혜, 박혜상(2005), "종이 접기를 응용한 플 리츠 의상 디자인 연구", 한국니트디자인학회 정기총회 및 춘계학술대회 학술발표논문집. pp.15-16.

16) 민경애(1996), "주름의 선을 이용한 의상디자인 연구”, 국민대학교 석사학위논문.

17) 이은경(1991), “복식에 표현된 'Pleats Design' 연구 -1940년대부터 현재까지를 중심으로-", 숙명여자대학교 석사학위논문.

18) 양희영(2007), "현대 패션에 나타난 주름의 조 형적 특성에 관한 연구 -라이프니츠와 들뢰즈 를 중심으로-", 한국복식학회, 57(1), pp.130146.

19) 김미성, 배수정(2000), "복식 디자인에 표현된 주름에 관한 연구 -Issey Miyake 작품을 중심 으로-", 한국가정관리학회 추계학술대회 학술발 표논문집. pp.156-156.

20) 김경희, 김미영(2006), "현대패션에 표현된 주 름장식에 관한 고찰”, 한복문화학회, $9(1)$, pp.27-41.

21) 김지영(2005), "주름에 의한 패션 디자인 -2000년대 이후 여성패션을 중심으로-”, 대한 가정학회, 43(5), pp.249-265.
22) 김창준(1991), 服饰辞典. 서울:라사라, p.31.

23) 박기원(1978), 圖解服饰用语事典, 서울:维新文化 社, p.186.

24) Pleats, 자료 출처:http://en.wikipedia.org/wiki/ Pleat

25) Charlotte Calasibeta(2002), Fairchild's Dictionary of Fashion, Laurence King.

26) Davis, Marian L.(1990). op.cit., p.65.

27) 이호정(1999), 패션디자인, 서울:교학연구사, pp.19-22.

28) 유송옥(1990), 복식의장학, 서울:수학사, pp. 42-44.

29) Davis, Marian L.(1990). op.cit., pp.66 68.

30) 김지영(2005), op.cit., p.251.

31) Davis, Marian L., op.cit., p.261.

32) Mc Jimsey, Harriet T. (1973). Art and Fashion in Clothing Selection. Ames:lowa State University Press, pp.130-131. 이호정, Op. Cit., pp.157-158에서 재인용.

33) 김지영(2005), op.cit., p.251.

34) Davis, Marian L.(1990), op.cit., pp.301- 311.

35) 이호정(1999), op.cit., p.20.

36) 박혜상(2004), "종이접기를 응용한 플리츠 의상 디자인 연구", 이화여자대학교 석사학위논문. p.26.

접수일(2012년 8월 1일),

수정일(1차 : 2012년 8월 20일, 2차 : 9월 3일), 게재확정일(2012년 9월 10일) 